\title{
ON SOME POINTS IN CHEMICAL GEOLOGY.
}

By David Forbes, F.R.S., etc.

In the "Chemical News" of October 4th, 1867, I commenced some remarks under this title, for the express purpose of exciting more interest in the application of Chemistry to Geology, and with the hope of starting a discussion which might at the same time enliven as well as elucidate the subject. Accepting Dr. Hunt's invitation,-his views, being the most recent, were first selected for consideration, and although that gentleman now appears greatly astounded at my presuming to differ from his opinions, it is still highly gratifying to find that he has at last condescended to reply.

As this. reply, however, contains absolutely nothing which can in any way affect or modify the opinions which I have already expressed on the views of Dr. Hunt, or even require a reconsideration of the arguments upon which those opinions were based, I am enabled to reply tout de suite.

Dr. Hunt adopts a line of argument which is an elaborate attempt to convince his readers of the utter incompetency and ignorance of his reviewer; yet, at the same time, it is amusing to observe that the character and tone of his remarks, in conjunction with his studious avoidance of some of the knotty points and more important arguments brought forward in opposition to his views, are strikingly suggestive of his being afflicted with a presentiment that there may after all be rickety points in his theoretical views.

Men who live in glass houses should not throw stones; Dr. Hunt's accusations of ignorance will appear strange to those who have paid attention to some of his sweeping assertions: amongst others, for example, when he emphatically declares that quartz "can only be generated by aqueous agencies," geologists will infer that Dr. Hunt must be ignorant of the most important fact, that quartz is found in abundance in volcanic lavas in many parts of the world, although not in Canada.

Had Dr. Hunt remained content with his Canadian laurels, he would probably have enjoyed them in peace without having his opinions disputed; but when he now aspires to be recognised in Europe, he cannot complain if his views be criticised by any or all of those interested in the subject-an ordeal which must be undergone before he can expect them to receive general acceptance, for surely he does not issue them as axioms or oracles. Europe differs greatly from Canada, and amongst other things, in close competition being the order of the day. No man in Europe can expect to retain any portion of the field of science exclusively for himself, or to travel alone on any of the many different roads which lead to one and the same scientific truth.

If real progress is to be made in science, the student must reason for himself, and not be content with accepting; merely on authority, opinions which are inconsistent with his own deductions or experiments; nor should he be deterred by the opposition to be expected 
from those already in office or autherity, who are sure to be jealous of intruders on what they imagine to be their own domain, and, doubtless, dislike having their peace of mind disturbed by innovations.

A discussion of this nature may be carried on in two ways, either by considering the main points of the argument first, before engaging in the minor details, or the reverse ; Dr. Hunt prefers the latter course, which, no doubt, is best suited to the defence of a weak cause, but' which his rather rambling remarks in last week's Chemical Nezes' will show is not calculated to convey to his reader any very clear idea of the exact points at issue, and is likely to confuse by then umber of minor details, having little or no bearing upon the main questions.

It is, therefore, most important for me that no misunderstanding should arise as to the exact points on which I have presumed to differ from the principles of chemical geology which Dr. Hunt has recently brought before the scientific public in Europe.

Expressed in as few words as possible, I object to the following of Dr. Hunt's assumptions or assertions :-

r. That the earth is solid to the core.

2. That the surface of the earth, immediately previous to its entire solidification, was " a liquid bath of no great depth surrounding the solid nucleus."

3. That the original atmosphere contained "the whole of the chlorine in the form of hydrochloric acid, the sulphur as sulphurous acid."

4. That the saltness of the sea is due to a rain of hydrochloric acid "flooding the half-cooled crust" with a highly heated acid deluge.

5. That the whole of "the calcareous strata, the marbles, and various limestones which we find on the earth's surface" have been precipitated from the sea by carbonate of soda.

6. That all the magnesian limestones and gypseous beds were formed in a dense at mosphere of carbonic acid.

7. That quartz "can only be generated by aqueous agencies."

8. "That granite is in every case a rock of sedimentary origin."

9. That volcanic rocks are merely ordinary sedimentary beds, melted by being "depressed, so that they come within the action of the earth's central heat."

Any minor differences fall naturally under these heads, and I may add that the perusal of Dr. Hunt's defence has confirmed me more than ever in the belief that the above premises are unsound, and I shall now endeavour, as concisely as possible, to examine the arguments pro et contra.

I. - The earth solid to the core.

Dr. Hunt seems to imagine that if the earth is not solid to the core, it can only consist of an immense central sphere of molten matter covered by a thin external crust or shell, for he wastes all his arguments in attempting to upset this theory, to which $I$ had never given my adhesion.

I have preferred adopting in the main the hypothesis of Bunsen, no mean authority, and when opposing Dr. Hunt's views simply asserted my opinion that the earth still encloses "a vast reservoir or reservoirs of still fluid igneous matter in its interior:" and the main argument with which I support this opinion is, that I consider that the molten lava ejected from volcanos must be derived from some such source. This is a very simple but common-sense view of the case, which I imagine Dr. Hunt will find some difficulty in refuting.

II. - That the earth's surface immediately previous to its entire solidification was "a liquid bath of no great depth surrounding the solid nucleus."

Hopkins has taken into favourable consideration the supposition that the earth actually was solid both in its centre and crust, and yet might retain fluid igneous matter in the intermediate space; and taking a somewhat similar view of the case, I believe that, even allowing that the solidification actually did commence at the

1 It is necessary to explain here that many of Dr. Hunt's observations refer to a previous communication in the October Number of the Geological MAGazine, and not to the subsequent one in the Chemical Nerus of Oct. 4, which, as is distinctly stated therein, is only supplementary to the former and to be read in conjunction with the same; yet Dr. Hunt indulges in the absurd accusation, that the contents of that communication have, "for some unknown reason, been withheld from the readers of the Chemical News." 
centre, it still could not have reached the exterior before, on the other hand, the surface itself had also solidified and formed a crust commencing from the exterior, due to the external cooling action.

In opposition to this, Dr. Hunt states that silicates, when cold, are from oneseventh to one-sixteenth part more dense than when molten, and would at once sink down into the fluid mass below, and further adds that no crust could be formed unless the laws of gravity were suspended. I do not know what Dr. Hunt's idea of the laws of gtavity may be, but I would merely again ask how far he imagines a crust of sp. gr. $2^{\circ} 6$ could sink down into a molten sphere of a mean sp. gr. $5 \cdot 3$. I will not, however, repeat the other arguments which I have used in the GEOLOGICAL MAGAZINE, but content myself by bringing forward one not before employed by me in support of my opinion.

Some experiments which I am now engaged in, on the effect of heat on bodies which contract in cooling, i.e. which are more dense when cold than when molten, show in the cases tried that a body upon the first application of heat expands and continues to do so up to near its melting point, when it contracts at the instant of fusion; in other words, although the substance when cold was heavier than when molten, yet the same substance expanded by heat was lighter than when molten. Thus, some metals were found to float about (like ice upon water) upon the surface of a molten bath of the same metal into which they were placed in a heated condition; 1 It appears probable that the same phenomena would account for such a crust as Dr. Hunt disputes, not siriking but floating on the molten bath below.

That the earth may possibly have solidified at the centre first, is not disputed by me, nor does its so doing in any way affect my' theoretical views. 'The object of 'my observations on this head was to show that we are altogether too ignorant of the character of the central mass of the earth, and of the effects likely to be produced by such enormous pressures, to be enabled to reason upon such insuffcient data with any confidence in the result.

III. - That the original atmosphere contained " the whole of the chlorine in the form of hydrochloric acid, the sulphur as sulphurous acid."

The perusal of Dr. Hunt's remarks does not in any way tend to modify the conclusions I had previously arrived at on this head. I still believe that chemists will not be disposed to regard an atmosphere containing enormous volumes of sulphurous acid, steam, and oxygen in excess, or in other words, which resembles a great sulphuric acid chamber, as probable; and as Dr. Hunt does admit that they would slowly unite to form sulphuric acid, it merely becomes a question of time as to whether they united slowly or quickly.

The arguments which I advance against supposing that such an atmosphere ever did exist are, that I consider that the sulphur would unite mainly with the heavier metals, and the chlorine mainly with the alkaline metals, and I consequently infer that these elements never went into the atmosphere in any such quantity as Dr. Hunt imagines.

Dr. Hunt, in opposition, states that sulphides could not be formed, since oxygen was in excess. Metallurgists know that sulphides are far less easily oxidizable than is generally imagined, and that they are produced in both blast and air-furnaces when the waste gases still contain unconsumed oxygen, and that time is an important element in this consideration.

But we have no proof whatever of any great excess of oxygen in the primeval atmosphere; on the contrary, we know that a vast amount of the oxygen now present in the air must have been derived from the decomposition of the carbonic acid, when the immense supplies of carbon afterwards buried in the various sedimentary formations were extracted from the atmosphere by the action of vegetable life. The slight excess of oxygen which, no doubt, was present would, further, be so diffused through the enormous volume of carbonic acid, nitrogen, and aqueous vapour, that it cannot be imagined to have exercised other than a most feeble oxidising action.

I As a metallurgist I have frequently observed such cases, but for a long time did not understand the explanation; I have to thank my friend Mr. Hackney for directing my attention to the behaviour of Bessemer steel under these circumstances, as it gives great trouble to the workmen by persistently floating high on the surface of the melted steel (even when in pieces of $40 \mathrm{lbs}$. or more) as long as its temperature is below its fusing point. 
The carbonic acid, also, being so infinitely more dense, and present in so overwhelming a quantity, would further act as a powerful shield against the very oxidising action which Dr. Hunt lays such stress upon.

That the chlorine did not go into the atmosphere, as Dr. Hunt imagines (combined with hydrugen as hydrochloric acid), I infer from the well-known far greater affinity which it has for sodium than for hydrogen, and the volatility of the sodium would be far more likely to bring it in contact with the chlorine than with the silica.

The idea that the action of the feeble excess of oxygen above alluded to, in connection with silica and steam, would prevent the formation of chloride of sodium, is not of much weight, since the chloride of sodium would be formed as a vapour in the atmosphere, while the silica remained below in the earthy mass in a solid form.

But Dr. Hunt next writes: "Even if, as Mr. Forbes supposes, the chloride of sodium were to be formed in the heated atmosphere, it would be precipitated into the intensely heated bath," etc. Precipitated! when it would be in the state of vapour at this temperature.

Metallurgists know how indifferent chloride of sodium is when fused with silicates, and to this property is due the employment of what is termed a salt-cover in assays; however well the salt may be intermixed, once the mass is fused it rises and swims on the top, and (if the heat be not too elevated or protracted as to volatilise it entirely) presents, upon cooling, a well-defined crystalline crust of salt, below which is found the unaltered silicate slag, and below this again the button of metal, pure or more or less in combination with sulphur, arsenic, antimony, etc., as the case may be; thus presenting, on the small scale, an illustration of what I have supposed may have occurred in nature, in which case also the cover or crust of salt would act as a shield against oxidation.

In a potter's kiln, the vapour of salt under confinement merely glazes the surface of the ware to a minute depth, which very glaze protects the silicates from further action; but both the potter's kiln and Gossage's soda-process are worked under forced circumstances, not applicable in this argument; and when Dr. Hunt explains that in his illustration of this subject he merely used the words, "if the elements zere made to react upon one another," is it not rather he who is trifling with the subject, when he supposes conditions which never could occur in nature in the case referred to.

IV. - That the saltness of the sea is due to a rain of hydrochloric acid "flooding the half cooled crust" with a highly heated acid deluge.

This assumption requires no further comments than those included under the preceding head, where $I$ have endeavoured to show that the whole of the chlorine did not ascend into the atmosphere as hydrochloric acid, and, consequently, could not flood the earth with the hot acid deluge insisted on by Dr. Hunt.

V. - That the whole of "the calcareous strata, the marbles and various limestones which we find on the earth's surface," have been precipitated from the sea by carbonate of soda.

Geologists have long agreed, that sedimentary limestones are the products of the action of organic life; and microscopists, in confirming this, have further proved that they do not possess the character of precipitates. Dr. Hunt evades any reply to these objections, but asks a question in return, requesting to know what becomes of the acid in case, as I contend, animals can utilize the salts of lime contained in the sea. As is well known, sulphur plays a very importan part in vital economy, entering both into the composition of organisms, and being also given off as sulphuretted hydrogen in the gaseous form. I see, therefore, many reasons for believing that animals do assimilate the sulphate of lime, which we know is contained in such an enormous quantity in the ocean.

VI. - That ail the magnesian limestones and gypseous strata were formed in a dense atmosphere of carbonic acid.

In 1846 , when in Birmingham, I was informed that for some years the manutacture of magnesian preparations was based upon the reactions of the compounds of magnesia with carbonic acid, in a compressed atmosphere of carbonic acid. In 1849, Mr. Osborne, a gentleman connected with a similar manufactory in Ireland, fully confirmed these statements, and shortly after the publication of Dr. Hunt's paper in the Comptes Rendus, Dr. Lawson, in the course of conversation, ex- 
pressed his surprise at Dr. Hunt being unaware of this, since he knew that the principle had been long in use in a manufactory at Cork.

Dr. Hunt has further applied this principle, ${ }^{1}$ and obtained very interesting results, which he considered to be the counterparts of nature's operations; and, remembering that there are dolomite beds in the lower Silurian strata of Canada, at once asks geologists to believe the rather hasty generalization that all the magnesian limestones and gypseous beds were formed in a dense atmosphere of carbonic acid.

Geologists, however, well knowing that the grand development of magnesian limestones and gypseous strata occurred in periods when air-breathing animals existed on the surface of the globe, could not believe that these animals actually lived in a dense atmosphere of carbonic acid; and had some of the more modern great gypseous formations occurred in Canada, Dr. Hunt would probably not have brought forward this theory.

VII. That quartz "can only be generated by aqueous agencies."

Dr. Hunt, wisely no doubt, does not take any notice of my arguments against this assertion, since they are facts, not opinions, and consist merely in pointing out that volcanic lavas of Italy, Hungary, Peru, Bolivia, Chili, etc., contain abundance of quartz often in well-defined crystals. In connection with this I may here extract a passage from a letter received from Mr. Sorby, who writes, "I have splendid cases of recent lavas with quartz; both in the shape of small crystals and as rounded masses, like those seen in some older rocks; and this quartz in both cases (crystals and rounded masses) contains splendid glass cavities, just like those in the felspars, the Arran pitchstone, and the various lavas ; thus we have complete proof, according to my views, that quartz both can and has crystallized out from a melted mass of rock." Now, in face of such facts; what importance, may I ask, can be attached to such of Dr. Hunt's dogmatic assertions as, "that the composition of the primitive crust would have excluded free silica?" that quartz "is only the result of a secondary process?" etc.

VIII.- "That granite is in every case a rock of sedimentary origin:"

Dr. Hunt makes this assertion in opposition to the opinion of many able men who have well studied the subject. If he, however, only founds this opinion on the presence of quartz in granite, the value to be attached to it may be inferred from the remarks contained in the preceding paragraph. If he speaks as a geologist, it may fairly be inquired whether he considers his Canadian experience sufficient to enable him to arrive at such sweeping generalization:

Sir Charles Lyell has stated that three things were essential to a geologist, namely, "to travel, to travel, and to travel ;" and such advice may be recommended to Dr. Sterry Hunt before he ventures again to generalize for the world on the strength of a local knowledge of a very minute part of the same.

IX.-That volcanic rocks are merely ordinary sedimentary beds, melted by being "depressed, so that they come within the action of the earth's central heat."

In the GEological MAGAzINE I ventured to inquire of "the author of this ingenious theory by what mechanical arrangement he supposes strata, on the surface of the earth, to be lowered down into a globe solid to the core;" and again, "how are we, according to this theory; to account for the fact that volcanic rocks, taken from any quarter of the world; no matter how far distant from one another-from Iceland or Terra del Fuego, from the Islands of the West Indies or from those of Polynesia-that in all cases such rocks possess an absolute identity in chemical and mineralogical composition, in physical and optical properties : can any geologist be expected to believe that such rocks have been formed by the melting up of a mere mechanical aggregate of rock débris, possessing no analogy whatsoever, and whose chemical composition, etc., is known to vary to the widest imaginable extremes?"-questions as yet unanswered.

Before concluding these remarks, I would here acknowledge that Dr. Hunt has discovered an inaccuracy which occurs in my communication to the Geological MAGAZINE, where the position of steam in the imaginary original attrosphere is by accident placed below that of air; although steam is in reality lighter-as a moment's reflection would have shown. This error has not the most minute influ: ence on any of my generalizations, as it is perfectly immaterial whether this stratum be above or below that of air.

I shall always be ready to admit at once any error which may be found in my 1 Vide Chemical News, Sept: 13,1867, p. 148.

VoL. V.-NO. XIIV. 
communications, and Dr. Hunt is quite entitled to make the most of such a blunder, if he considers it will support his views; at the same time I trust that he will also be equally candid in cases where he may be found tripping.

Dr. Hunt alludes to a rough sketch of some of my views contained in the GEological MAGaziNe; but as I have already accepted the invitation of the Council of the Chemical Society to give a lecture on Chemical Geology (2oth February next), Dr. Hunt will thus be enabled to take my views into full consideration, and after comparing them with his own I trust he will give us the benefit of his scrutiny; for as I regard the ultimate object of all my labours as being the attainment of scientific truth, I am as fully prepared to be corrected in points where I may be proved to be wrong as to defend those which I hold to be right.

\section{THE BOULDER-CLAY AT WITHAM AND THE THAMES VALLEY.}

SIr,-Mr. Dawkins has spoken of the occurrence of a Boulder-clay at Witham as affording a presumption that the valley there is older than the glacial drift. I am able to give a rough section of the boring for the well in which it occurred, where I saw it in 1865 . I obtained the depths from the men at work, in answer to questions regarding the stuff which I saw to have been brought up.

SECTION OF ARTESIAN WEII AT WITHAM STATION, ESSEX.

Feet.

Coarse gravel

Greyish Glacial clay, with large flints and chalk pebbles ........................
Fine clayey sand, brown and green, with green-coated flints at the bottom,

(Thames sand)

150

Chalk, in which the water was obtained.

The spot is more than 20 feet above the stream, so that the gravel is a terrace gravel; and, in what is probably the same bed, I found a short time previously a good specimen of an oval flint implement: I picked it off a heap in the gravel-pit, at the entrance of the lane which leads to the Goods' Depôt.

Now, as regards the glacial clay in this section, there is a peculiarity which at the time surprised me much. I allude to the entire absence of anything like the "middle drift" beneath it. This drift occurs in full force along the high ground to the south, by Danbury and Wickham Bishops; and Mr. S. V. Wood, jun., has shown it in section 9 of his paper on the Essex valleys, ${ }^{1}$ as underlying the Boulderclay at Little Braxted close by. A glance at that section will show that the position of the Boulder-clay at Little Braxted has no analogy. with that at Witham Station, where it extends many feet below the bottom of the valley. These circumstances, to my mind, throw a considerable doubt upon the clay at the station being the true Boulder-drift; and if it be not, we cannot argue from it that the valley is older than the Boulder-drift.

We are told of the existence of several Boulder-clays-and I can myself speak to a Boulder-clay occupying a valley in Essex which is clearly newer than the true Boulder-drift. It is to be seen on the shore, beneath the terrace, at Walton-on-the-Naze. It contains Chalk pebbles, large flints, London clay septaria, and Crag sand, and is full of mammalian bones. In hard specimens it could not be distinguished from the older Boulder-clay.

I have not a sufficiently minute acquaintance with the neighbour-

1 Grol. MAa., Vol. III. p. 348, map. 